\title{
Analisis Kemampuan Pemahaman Konsep Matematis pada Materi SPLDV Ditinjau dari Gaya Belajar Peserta Didik
}

\author{
Aprilia Khoirunnisa ${ }^{1}$, Slamet Soro ${ }^{2}$ \\ ${ }^{1,2}$ Prodi Pendidikan Matematika, Fakultas Keguruan dan Ilmu Pendidikan, Universitas Muhammadiyah Prof. Dr. Hamka, \\ Jl. Tanah Merdeka No.20, Kota Jakarta Timur, Daerah Khusus Ibukota Jakarta 13830 \\ apriliakhoirunnisa01@gmail.com
}

\begin{abstract}
This study aims to describe the understanding of the concepts of class X MIPA 2 students' at SMAN 5 Jakarta in solving the problem of a linear equation system of two variables with reference to learning styles, namely by visual, auditory, and kinesthetic. The type of study applied in this study is a qualitative approach with descriptive methods. Six students were selected as subjects, which are two students who represented each learning styles. The Miles and Huberman model was used to analyze the data obtained in this study, specifically data reduction, data presentation, and drawing conclusions. The outputs show that students of all three learning styles are capable to understand the concept of a linear equation system of two variables, but students with visual learning styles are the ones that best meet all of the indicators of concept understanding, surpassing students with auditory and kinesthetic learning styles who are still unable to distinguish between examples and non-examples of a concept.
\end{abstract}

Keywords: Concept Understanding, Learning Styles

\begin{abstract}
Abstrak
Penelitian ini dilakukan dengan tujuan menganalisis kemampuan pemahaman konsep yang dimiliki peserta didik kelas X MIPA 2 SMAN 5 Jakarta dalam menyelesaikan masalah sistem persamaan linear dua variabel dengan meninjau dari gaya belajar peserta didik, yaitu visual, auditorial, dan kinestetik. Pendekatan kualitatif dengan metode deskriptif digunakan dalam penelitian ini. Subjek yang dipilih sebanyak enam orang yang merupakan dua peserta didik yang mewakili masing-masing gaya belajar. Model Miles dan Huberman digunakan untuk menganalisis data yang diperoleh dalam penelitian ini, yaitu dengan reduksi data, penyajian data, dan penarikan kesimpulan. Hasilnya menunjukkan bahwa peserta didik yang memiliki ketiga gaya belajar VAK mampu memahami konsep SPLDV, namun gaya belajar visual yang paling memenuhi seluruh indikator pemahaman konsep melebihi peserta didik dengan gaya belajar auditorial dan kinestetik yang masih belum mampu membedakan contoh dan bukan contoh dari sebuah konsep.
\end{abstract}

Kata kunci: Pemahaman Konsep, Gaya Belajar

Copyright (c) 2021 Aprilia Khoirunnisa, Slamet Soro

$\square$ Corresponding author: Aprilia Khoirunnisa

Email Address: apriliakhoirunnisa01@gmail.com (Jl. Tanah Merdeka No.20, Jakarta Timur, DKI Jakarta 13830)

Received 13 July 2021, Accepted 18 July 2021, Published 06 August 2021

\section{PENDAHULUAN}

Kualitas sumber daya manusia menjadi penentu untuk kemajuan suatu bangsa. Kualitas pendidikan memiliki andil besar dalam kualitas sumber daya manusia. Pendidikan memiliki peran penting untuk melahirkan masyarakat yang damai, cerdas, demokratis dan terbuka (Kepa, 2019, hal. 72). Dalam hal ini, tentunya pendidikan merupakan kata kunci dalam mengembangkan pengetahuan dan kualitas peserta didik. Sejalan dengan yang dikatakan oleh Muhardi (2005, hal. 480) bahwa kunci utama dalam meningkatkan kualitas suatu bangsa adalah pendidikan. Itulah mengapa, pembaharuan dalam pendidikan patut dengan senantiasa dilakukan guna meningkatkan kualitas pendidikan dari suatu bangsa, sehingga dapat mewujudkan bangsa yang berkemajuan dan tentunya berkualitas.

Undang-Undang Nomor 20 Tahun 2003 tentang sistem pendidikan mengemukakan bahwa 
pendidikan merupakan usaha terencana dan sadar untuk memanifestasikan suasana belajar dan proses pembelajaran agar peserta didik secara aktif meningkatkan kecakapan dirinya sehingga mempunyai keterampilan, kepribadian, pengendalian diri, akhlak mulia, kecerdasan, serta kekuatan spiritual yang diperlukan oleh dirinya, masyarakat, bangsa dan negara. Tujuan utama dari pendidikan itu sendiri tertuang di dalam undang-undang tersebut, yaitu untuk mencerdaskan dan mengembangkan manusia Indonesia seutuhnya, yaitu manusia yang bertakwa dan beriman terhadap Tuhan Yang Maha Esa dan memiliki pengetahuan, keterampilan, dan budi pekerti luhur, kesehatan jasmani dan rohani, memiliki kepribadian yang mantap dan mandiri, serta memiliki rasa tanggungjawab kebangsaan dan kemasyarakatan.

Dibutuhkan usaha untuk menunjang pendidikan sebagai bentuk mengimplementasikan tujuan pendidikan. Salah satu usaha yang dapat dilakukan yaitu dengan mendirikan sarana-sarana pendidikan, seperti taman kanak-kanak, sekolah, universitas, dan lembaga penunjang pendidikan lainnya. Pendidikan formal di Indonesia pada umumnya diterapkan dalam program wajib belajar 12 tahun (Hasanah \& Mutiani, 2019, hal. 16). Umumnya, sekolah menjadi sarana program wajib belajar 12 tahun dilaksanakan. Berdasarkan tingkatannya, ada beberapa jenjang sekolah yang berbeda-beda, seperti SD, SMP, SMA, SMK, dan sederajatnya. Pada setiap jenjangnya, sekolah mempunyai banyak subjek pelajaran yang bisa diajarkan kepada peserta didik, dan salah satunya adalah mata pelajaran matematika.

Pelajaran matematika termasuk salah satu subjek pelajaran yang wajib diajarkan di setiap jenjang pendidikan sekolah sejak dari sekolah dasar hingga sekolah menengah atas. Bahkan, seorang anak sudah diperkenalkan tentang cara berhitung sebelum dirinya memasuki sekolah dasar, misalnya saat anak berada di bangku taman kanak-kanak atau PAUD. Matematika mempunyai andil yang cukup besar di dalam kehidupan, mulai dari benda-benda di sekitar yang memiliki hubungan kuat dengan matematika, hingga aktivitas-aktivitas yang membutuhkan matematika (Yulia, 2019, hal. 24). Itulah sebabnya mengapa matematika penting untuk dikuasai oleh setiap peserta didik agar dapat lebih mudah menangani masalah yang erat hubungannya dengan matematika di dalam kehidupan.

Pada dasarnya, matematika adalah sebuah ilmu yang tidak terelakkan dan diperlukan di berbagai bidang. Matematika memenuhi kebutuhan di berbagai bidang di masa kini dan di masa mendatang. Mempelajari matematika merupakan hal yang sangat penting bagi peserta didik, karena peserta didik akan memiliki pola pikir yang logis dengan mempelajari matematika, sehingga akan menjadi manfaat untuk membantu menyelesaikan masalah di dalam kehidupan. Keberhasilan dalam mempelajari matematika akan membukakan pintu karir yang cerah dalam kehidupan seorang peserta didik. Matematika akan membantu menunjang proses pengambilan keputusan, sehingga peserta didik memiliki kemampuan untuk bersaing di berbagai bidang.

Dalam mempelajari matematika di masa kini membutuhkan kemampuan dalam pemahaman konsep untuk membantu menyelesaikan masalah matematika. Pemahaman berasal dari kata paham, yang menurut Kamus Besar Bahasa Indonesia diartikan sebagai mengerti benar, sedangkan pemahaman itu sendiri diartikan sebagai proses perbuatan memahami (Yulianty, 2019, hal. 61). Karunia dan Mulyono (2016, hal. 337) mengatakan bahwa pemahaman dalam konsep merupakan hal yang mendasari peserta didik memiliki 
kemampuan pemecahan masalah matematika. Pemahaman konsep dapat diartikan sebagai sebuah permulaan atau awal untuk memahami materi yang dipelajari agar peserta didik memiliki pengalaman untuk mempelajari materi pada mata pelajaran matematika (Wijayanti et al., 2018, hal. 158). Oleh karena itu, pemahaman konsep terhadap mata pelajaran matematika sangat penting dan perlu ditanamkan kepada peserta didik.

Pemahaman konsep juga merupakan dasar dari pemahaman teori-teori, sehingga untuk memahami teori, terlebih dahulu peserta didik harus memahami konsep-konsep yang menyusun teori tersebut (Diana et al., 2020, hal. 25). Sedangkan Dali (Susilaningsih et al., 2019, hal. 86) menyatakan: "Conceptual understanding is the ability of a person to be able to explain, differentiate, give examples and connect a concept of what he knows with new knowledge." Pernyataan Dali tersebut berarti bahwa kemampuan konsep seseorang yaitu menjelaskan, membedakan, memberi contoh dan menghubungkan apa yang diketahui dengan pengetahuan yang baru.

Tujuan pertama pembelajaran matematika menurut Depdiknas (Permendiknas no. 22 tahun 2006) mencakup pentingnya pemahaman dalam konsep matematika, yaitu memahami konsep matematika, menjelaskan keterkaitan antar konsep dan mengaplikasikan algoritma atau konsep secara akurat, luwes, tepat, dan efisien dalam pemecahan masalah. Sesuai dengan tujuan dalam pembelajaran matematika yang disebutkan, dalam proses pembelajarannya peserta didik diharapkan mampu memahami konsep dalam matematika agar kelak dapat menggunakan kemampuan tersebut untuk membantu memecahkan masalah terkait matematika.

Dalam memproses suatu informasi, masing-masing peserta didik mempunyai karakteristik yang berbeda antar peserta didik yang lainnya, yang mengakibatkan peserta didik menempuh gaya yang berbeda untuk memahami konsep. Salah satu karakteristik peserta didik yang perlu diperhatikan pada saat proses pembelajaran ialah gaya belajar atau learning styles. Hal ini sejalan dengan yang dikatakan Karunia dan Mulyono (2016, hal. 339) bahwa selain memperhatikan penggunaan model pembelajaran, seorang pendidik diharapkan mampu memperhatikan gaya belajar yang dimiliki peserta didik agar pengetahuan yang didapatkan dapat diserap dengan maksimal sesuai gaya belajar yang dimilikinya.

Menurut DePorter dan Hernacki, berdasarkan modalitas belajar ada tiga gaya belajar yang umumnya dikenal, yaitu: (1) Visual, melibatkan indera penglihatan; (2) Auditorial, melibatkan indera pendengaran; dan (3) Kinestetik, melibatkan gerakan anggota tubuh.

Gaya belajar visual difokuskan pada ketajaman pada indera penglihatan, artinya peserta didik harus menyaksikan bukti-bukti absolut terlebih dahulu supaya lebih mudah memahami suatu materi (Nurhidayah, 2015, hal. 15). Peserta didik yang mempunyai gaya belajar visual cenderung memiliki keinginan yang tinggi untuk melihat dan memproses informasi secara visual sebelum ia memahaminya. Gaya belajar auditorial umumnya memanfaatkan indera pendengaran untuk mempermudah proses belajar (Wahyuni, 2017, hal. 129). Artinya, peserta didik menyerap informasi melalui apa yang didengarnya. Peserta didik yang memiliki gaya belajar auditorial dapat mempelajari informasi dengan lebih cepat saat melakukan diskusi verbal dan mendengarkan apa yang disampaikan pendidik secara lisan atau melalui perantara suara. 
Peserta didik yang memiliki gaya belajar kinestetik umumnya mengandalkan mencerna informasi melalui menyentuh, keaktifan bergerak, dan melakukan tindakan (Astari, 2018, hal. 5). Peserta didik kinestetik umumnya tidak bisa membiarkan dirinya untuk duduk diam terlalu lama, mereka memiliki keinginan yang kuat untuk beraktivitas dan melakukan eksplorasi.

Ketiga gaya belajar tersebut umumnya dimiliki setiap peserta didik, namun ada satu gaya belajar yang paling dominan dimilikinya. Berdasarkan pernyataan tersebut, setiap peserta didik dipastikan memiliki kecenderungan terhadap satu gaya belajar tertentu. Gaya belajar yang dimaksud peneliti dalam penelitian ini adalah gaya belajar yang diklasifikasikan sebagai kemampuan yang dimiliki peserta didik dalam memahami konsep matematika. Sehingga peneliti berminat melakukan penelitian dengan judul "Analisis Kemampuan Pemahaman Konsep Matematika ditinjau dari Gaya Belajar Peserta Didik”.

\section{METODE}

\section{Jenis Penelitian}

Jenis kualitatif digunakan sebagai pendekatan dalam penelitian ini. Penelitian ini menggunakan teknik purposive sampling atau sampel bertujuan sebagai cara pengambilan subjek. Menurut Sugiyono dalam Jaenudin dkk (2017, hal. 72), purposive sampling merupakan teknik pengambilan sumber data dengan pertimbangan tertentu. Metode yang digunakan oleh peneliti dalam penelitian ini adalah jenis metode deskriptif dikarenakan pada penelitian ini mendeskripsikan atau menggambarkan analisis kemampuan memahami konsep matematika pada Sistem Persamaan Linear Dua Variabel (SPLDV) ditinjau dari gaya belajar peserta didik. Selanjutnya respons yang berupa penyelesaian tersebut dianalisis.

Model Miles dan Huberman digunakan dalam penelitian ini untuk melakukan analisis data, yaitu di antaranya adalah mereduksi data, menyajikan data, dan menarik kesimpulan (Sugiyono, 2013). Pada proses mereduksi data, peserta didik dikelompokkan menjadi tiga jenis gaya belajar, yaitu peserta didik dengan gaya belajar visual, auditorial, dan kinestetik. Selanjutnya, data disajikan dalam bentuk deskripsi kemampuan pemahaman konsep SPLDV ditinjau dari gaya belajar peserta didik, lalu dilakukan penarikan kesimpulan yang dibuat sesuai dengan hasil dari analisis data yang telah dijabarkan.

\section{Subjek Penelitian}

Subjek yang dipilih peneliti yaitu peserta didik dari kelas X MIPA 2 di SMAN 5 Jakarta yang masingmasing terdiri dari dua peserta didik yang mempunyai gaya belajar visual, auditorial, dan kinestetik. Subjek dalam penelitian ini dan gaya belajar yang mereka miliki disajikan ke dalam Tabel 1. di bawah ini

Tabel 1. Subjek Penelitian

\begin{tabular}{|c|c|}
\hline Inisial Subjek & Gaya Belajar \\
\hline AA & Visual \\
\hline NA & Visual \\
\hline AKK & Auditorial \\
\hline SBB & Auditorial \\
\hline ML & Kinestetik \\
\hline SAH & Kinestetik \\
\hline
\end{tabular}




\section{Instrumen Penelitian}

Instrumen utama dalam penelitian ini ialah human instrument atau orang, yaitu peneliti sendiri. Selain itu, Kuesioner Gaya Belajar dan Tes Uraian Pemahaman Konsep SPLDV yang sesuai dengan indikator pemahaman konsep juga menjadi instrument pendukung dalam penelitian ini. Kedua instrumen pendukung dilakukan uji validitas dterlebih dahulu sebelum digunakan untuk mengumpulkan data. Selanjutnya, butir soal yang valid dari kedua instrumen tersebut diuji reliabilitasnya untuk mengetahui apakah instrumen tersebut merupakan alat ukur yang reliabel. Triangulasi waktu digunakan dalam penelitian ini guna memeriksa keabsahan data.

\section{Prosedur Pengumpulan Data}

1. Tahap perencanaan, yaitu melakukan survei ke lokasi untuk penelitian, mengajukan surat sebagai permohonan untuk menjalankan penelitian, merancang alat ukur penelitian yang meliputi: kuesioner gaya belajar dan tes pemahaman konsep, melaksanakan uji kelayakan terhadap alat ukur penelitian, melakukan analisis hasil uji kelayakan instrumen penelitian, kemudian melakukan revisi terhadap alat ukur tersebut.

2. Tahap pelaksanaan, yaitu kuesioner atau angket gaya belajar diberikan kepada partisipan yaitu seluruh peserta didik dari kelas X MIPA 2 di SMA Negeri 5 Jakarta, kemudian memilih dua subjek dari masingmasing gaya belajar (visual, auditorial, dan kinestetik), dan memberikan tes pemahaman konsep kepada subjek terpilih.

3. Tahap analisis data, yaitu dengan mereduksi data, melakukan penyajian data, dan menarik kesimpulan.

4. Tahap penyusunan laporan dalam bentuk artikel.

\section{HASIL DAN DISKUSI}

Hasil

Peneliti dalam pengambilan data tes pemahaman konsep menggunakan triangulasi waktu, yang bertujuan untuk memastikan data tetap kredibel. Setiap subjek diberikan soal tes uraian SPLDV di 3 hari yang berbeda dengan soal tes yang sama namun dengan urutan yang diacak. Tes pertama diberikan di hari Rabu dengan alokasi waktu $3 \times 40$ menit, tes kedua dan ketiga diberikan di hari selanjutnya, yaitu Kamis dan Jumat dengan alokasi waktu yang sama. Tes pemahaman konsep SPLDV terdiri dari 12 butir soal yang telah teruji valid dan memiliki tingkat reliabilitas tinggi. Skor hasil tes yang diperoleh msing-masing subjek dapat dilihat pada tabel berikut dengan urutan butir soal tes kedua dan ketiga sudah disesuaikan dengan soal tes pertama:

Tabel 2. Hasil Tes Pemahaman Konsep Matematika Hari Pertama, Kedua, dan Ketiga

\begin{tabular}{|c|c|c|c|c|c|c|c|c|c|c|c|c|c|c|c|}
\hline \multirow{2}{*}{ Hari } & \multirow{2}{*}{ Subjek } & \multirow{2}{*}{$\begin{array}{c}\text { Gaya } \\
\text { Belajar }\end{array}$} & \multicolumn{12}{|c|}{ Butir Soal } & \multirow{2}{*}{$\begin{array}{l}\text { Skor } \\
\text { Total }\end{array}$} \\
\hline & & & 1 & 2 & 3 & 4 & 5 & 6 & 7 & 8 & 9 & 10 & 11 & 12 & \\
\hline \multirow{5}{*}{ I } & AA & $\mathrm{V}$ & 4 & 4 & 4 & 4 & 4 & 4 & 4 & 3 & 4 & 4 & 4 & 4 & 47 \\
\hline & NA & V & 4 & 4 & 4 & 4 & 4 & 4 & 4 & 4 & 4 & 4 & 4 & 4 & 48 \\
\hline & AKK & A & 2 & 1 & 4 & 1 & 4 & 1 & 4 & 4 & 4 & 4 & 4 & 4 & 37 \\
\hline & SBB & A & 2 & 4 & 4 & 4 & 3 & 3 & 3 & 4 & 4 & 4 & 3 & 4 & 42 \\
\hline & ML & $\mathrm{K}$ & 1 & 1 & 4 & 1 & 3 & 1 & 3 & 4 & 4 & 4 & 4 & 4 & 34 \\
\hline
\end{tabular}




\begin{tabular}{|c|c|c|c|c|c|c|c|c|c|c|c|c|c|c|c|}
\hline & SAH & K & 4 & 4 & 2 & 2 & 4 & 4 & 4 & 4 & 4 & 4 & 4 & 4 & 44 \\
\hline \multirow{6}{*}{ II } & AA & $\mathrm{V}$ & 4 & 4 & 4 & 4 & 4 & 4 & 4 & 3 & 4 & 4 & 4 & 4 & 47 \\
\hline & NA & $\mathrm{V}$ & 4 & 4 & 4 & 4 & 4 & 4 & 4 & 4 & 4 & 4 & 4 & 4 & 48 \\
\hline & AKK & A & 2 & 1 & 4 & 1 & 4 & 1 & 4 & 4 & 4 & 4 & 4 & 4 & 37 \\
\hline & SBB & A & 4 & 4 & 4 & 4 & 3 & 4 & 4 & 3 & 3 & 4 & 4 & 4 & 45 \\
\hline & ML & K & 1 & 1 & 4 & 1 & 3 & 1 & 4 & 4 & 4 & 4 & 4 & 0 & 31 \\
\hline & SAH & $\mathrm{K}$ & 4 & 4 & 4 & 2 & 4 & 4 & 4 & 4 & 4 & 4 & 4 & 4 & 46 \\
\hline \multirow{6}{*}{ III } & AA & V & 4 & 4 & 4 & 4 & 4 & 4 & 4 & 3 & 4 & 4 & 4 & 4 & 47 \\
\hline & NA & $\mathrm{V}$ & 4 & 4 & 4 & 4 & 4 & 4 & 4 & 4 & 4 & 4 & 4 & 4 & 48 \\
\hline & AKK & $\mathrm{A}$ & 4 & 4 & 4 & 2 & 4 & 4 & 4 & 4 & 4 & 4 & 4 & 4 & 46 \\
\hline & SBB & $\mathrm{A}$ & 4 & 4 & 4 & 4 & 4 & 3 & 3 & 4 & 4 & 4 & 4 & 4 & 46 \\
\hline & ML & K & 4 & 4 & 4 & 2 & 4 & 4 & 4 & 4 & 4 & 4 & 4 & 4 & 46 \\
\hline & SAH & $\mathrm{K}$ & 4 & 4 & 4 & 2 & 4 & 4 & 4 & 4 & 4 & 4 & 4 & 3 & 41 \\
\hline
\end{tabular}

Indikator utama dalam pemahaman konsep menjadi hal yang ditekankan pada penelitian ini, yaitu: (a) menyatakan ulang suatu konsep, yang diwakili butir soal nomor 1 dan 2; (b) mengklasifikasi objek berdasarkan sifat-sifat tertentu yang sesuai dengan konsepnya, yang diwakili butir soal nomor 3; (c) memberi contoh dan bukan contoh dari suatu konsep yang dijelaskan, yang diwakili butir soal nomor 4 dan 5; (d) menyajikan konsep dalam berbagai bentuk representasi matematika, yang diwakili butir soal nomor 6 dan 7; (e) mengembangkan persyaratan yang diperlukan atau persyaratan yang memenuhi dari sebuah konsep, yang diwakili butir soal nomor 8 dan 9; (f) memanfaatkan, menggunakan, dan memilih operasi atau prosedur tertentu, yang diwakili soal butir nomor 10; dan (g) mengaplikasikan algoritma atau konsep dalam memecahkan masalah, yang diwakili butir soal nomor 11 dan 12 .

\section{Diskusi Hasil Subjek Dengan Gaya Belajar Visual}

Subjek AA dan NA adalah peserta didik yang memiliki gaya belajar visual, keduanya memiliki perolehan skor yang tinggi di setiap butir soal dalam tiga kali waktu tes. Pada butir soal nomor 8, subjek AA memperoleh skor 3 dari 4 skor yang bisa diperoleh karena subjek AA masih sedikit kurang cukup mengembangkan persyaratan yang diperlukan atau persyaratan yang memenuhi dari soal yang tersedia, yaitu tidak menggambarkan grafik sesuai perintah. Secara keseluruhan, subjek visual menjelaskan interpretasi yang ditanyakan secara rinci dan teratur serta menyajikan grafik dengan sangat jelas dan rapi. Masing-masing dapat dikatakan dapat memahami dan menafsirkan konsep materi SPLDV dengan baik.

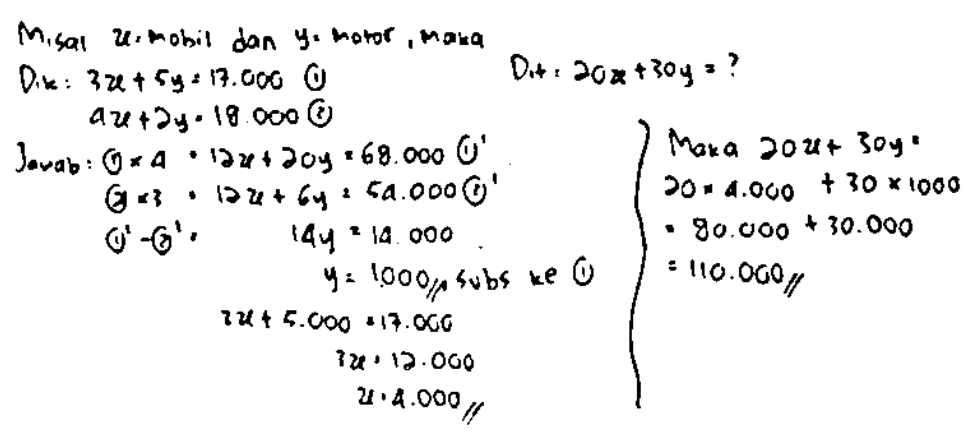

Gambar 1. Jawaban Subjek NA Untuk Indikator Kedua 


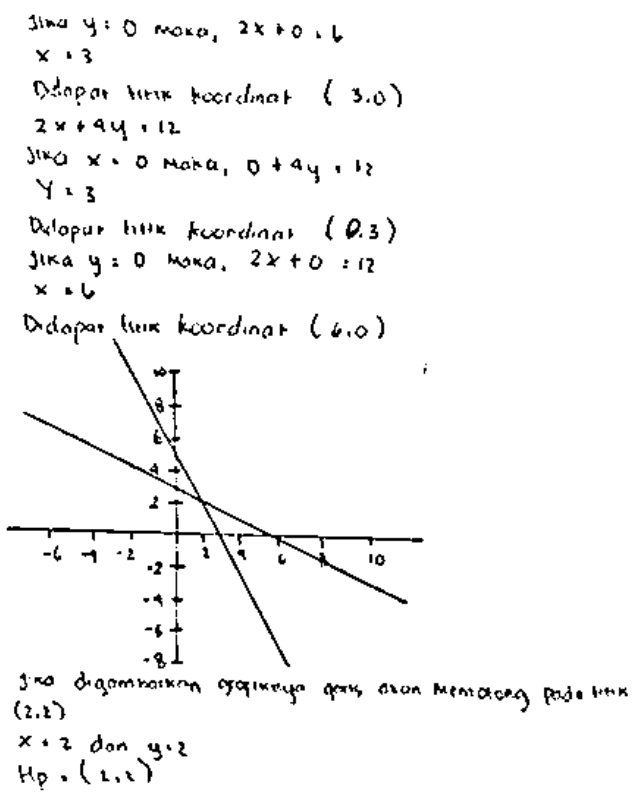

Gambar 2. Jawaban Subjek AA Untuk Indikator Keempat

\section{Diskusi Hasil Subjek Dengan Gaya Belajar Auditorial}

Dua subjek yang memiliki gaya belajar auditorial adalah subjek AKK dan SBB. Subjek AKK mengalami kesulitan memahami beberapa konsep di hari tes ke I dan II, yaitu di butir soal nomor 1,2, 4,dan 6. Pada indikator pertama yaitu menyatakan ulang suatu konsep, subjek AKK tidak dapat menyatakan ulang konsep dengan baik. Kemampuannnya untuk membedakan contoh dan bukan contoh sesuai indikator ketiga belum terpenuhi, karena subjek AKK hanya dapat memberikan contohnya saja. Subjek AKK juga tidak dapat menyajikan sebuah konsep dalam bentuk representasi matematika sesuai indikator keempat, karena tidak menggambarkan grafik yang seharusnya dapat disajikan sesuai perintah. Namun, di hari ke III, subjek AKK sudah mampu memenuhi indikator-indikator tersebut, sehingga dapat dikatakan cukup mampu memahami konsep SPLDV.

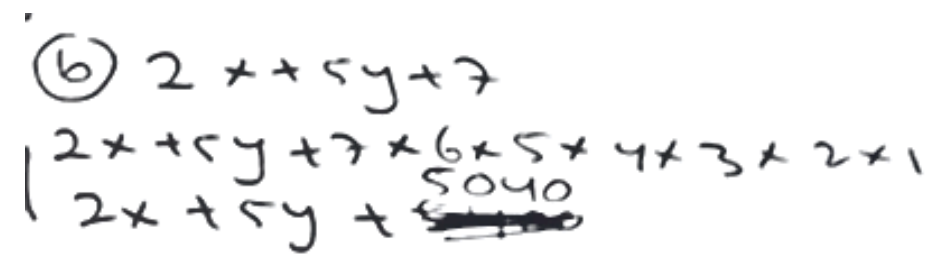

Gambar 3. Jawaban Subjek AKK Untuk Indikator Pertama

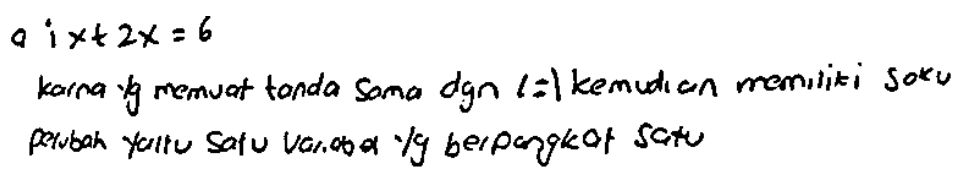

Gambar 4. Jawaban Subjek AKK Untuk Indikator Ketiga 


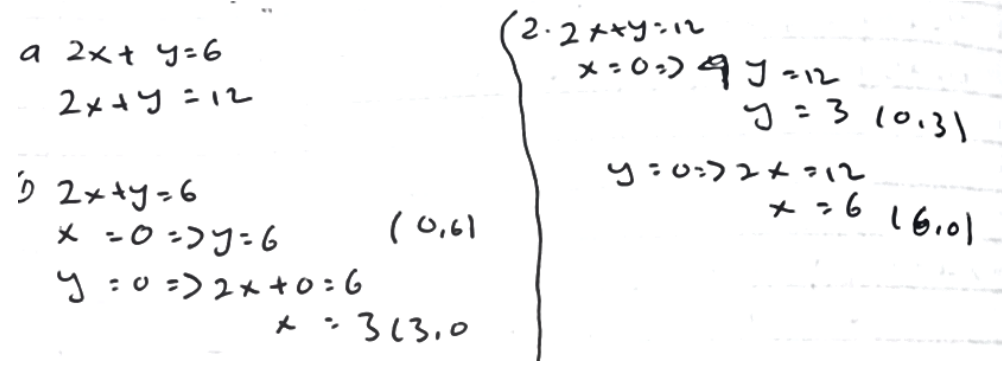

Gambar 5. Jawaban Subjek AKK Untuk Indikator Keempat

Subjek SBB yang sama-sama memiliki gaya belajar auditorial dengan subjek AKK, di hari I dapat menyatakan ulang konsep sesuai indikator pertama tetapi masih memiliki kesalahan yaitu belum dapat menyebutkan koefisien, variabel, dan konstanta dari sebuah persamaan. Sementara pada indikator lainnya, subjek SBB telah cukup memenuhi indikator-indikator itu. Subjek SBB memiliki rata-rata perolehan skor tinggi, terutama pada hari ke II dan III tes, sehingga dapat dikatakan cukup memahami konsep SPLDV.

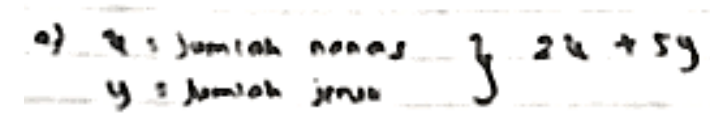

Gambar 6. Jawaban Subjek SBB Untuk Indikator Pertama

Secara keseluruhan, dalam menginterpretasi masalah berdasarkan konsep matematika yang disajikan, subjek auditorial tidak menjelaskan secara rinci interpretasi yang ditanyakan, cenderung langsung menjelaskan perhitungan ke intinya, namun masih bisa dipahami seperti yang tertera pada Gambar 7 di bawah.

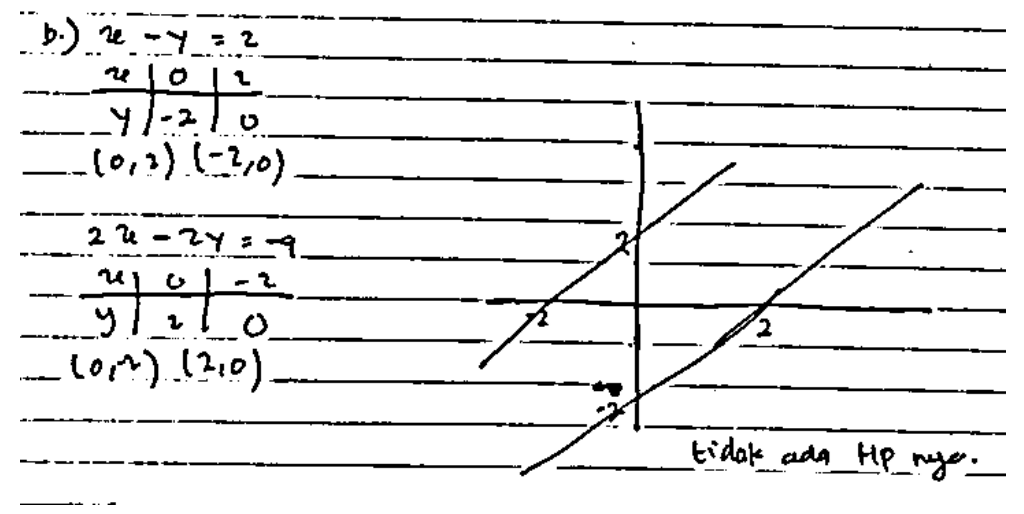

Gambar 7. Jawaban Subjek SBB Untuk Indikator Kelima

\section{Subjek dengan Gaya Belajar Kinestetik}

Subjek yang memiliki gaya belajar kinestetik yaitu subjek ML dan SAH. Subjek ML terlihat mengalami kesulitan pada butir soal nomor 1, 2, 4, 6 dan 12 di hari tes ke I dan II. Dalam menyatakan ulang konsep, yaitu indikator pertama di hari tes ke I dan II, subjek ML belum dapat memenuhinya dengan baik karena tidak dapat menyebutkan koefisien, variabel, dan konstanta yang diminta dalam butir soal. Subjek ML juga belum mampu memberi contoh dan bukan contoh dari SPLDV pada indikator ketiga. Masih di hari tes yang sama, subjek ML juga belum dapat menyajikan sebuah konsep dalam bentuk representasi matematika sesuai dengan indikator keempat. Di hari tes I, subjek ML mampu mengaplikasikan algoritma 
atau konsep sesuai dengan indikator ketujuh, namun subjek ML memberikan jawaban kosong dengan skor 0 di hari tes ke II. Dapat dikatakan bahwa subjek ML masih kurang memahami konsep SPLDV pada tes hari ke I dan II. Namun di hari ke III tes, subjek ML mampu memperoleh rata-rata skor yang baik pada indikator-indikator tersebut, yang artinya subjek ML mampu memahami konsep SPLDV, walau masih ada sedikit kekurangan dalam membedakan contoh dan yang bukan contoh dari konsep SPLDV.

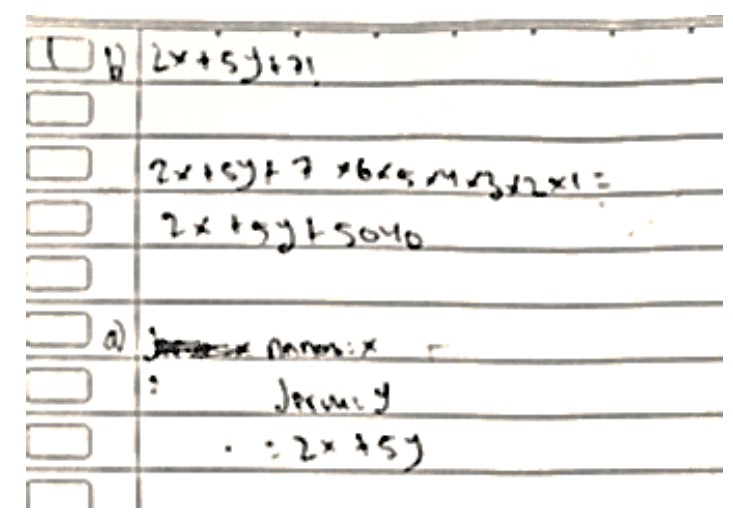

Gambar 8. Jawaban Subjek ML Untuk Indikator Pertama

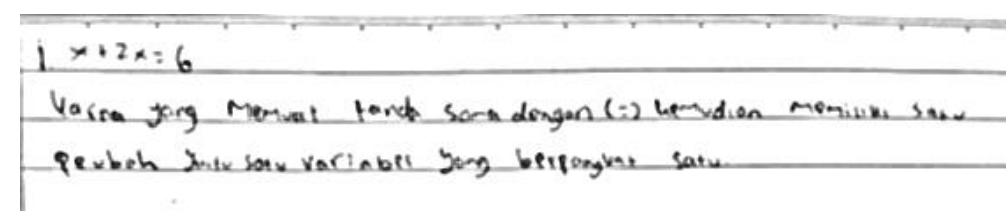

Gambar 9. Jawaban Subjek ML Untuk Indikator Ketiga

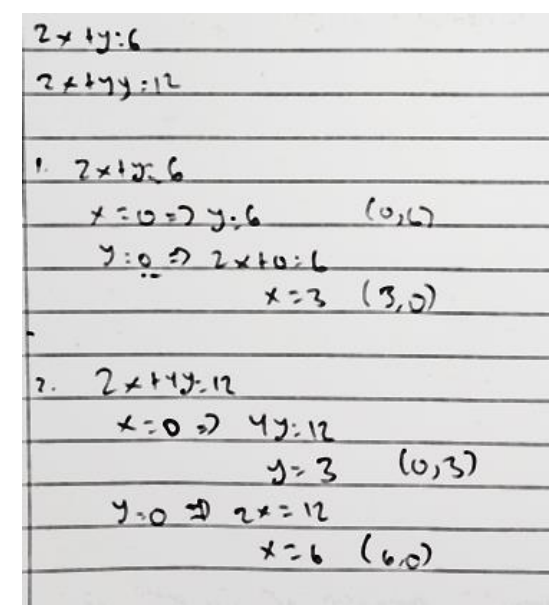

Gambar 10. Jawaban Subjek ML Untuk Indikator Keempat

Sedangkan subjek SAH, memiliki rata-rata skor cukup baik dalam tiga kali tes dan dapat memahami konsep SPLDV dengan cukup baik, walau dengan sedikit ketidaktepatan saat memberi contoh dan yang bukan contoh suatu konsep sesuai dengan indikator ketiga, karena hanya dapat menjelaskan contoh SPLDV dan tidak menjelaskan yang bukan contoh dari SPLDV di hari ke I, II, dan III. 


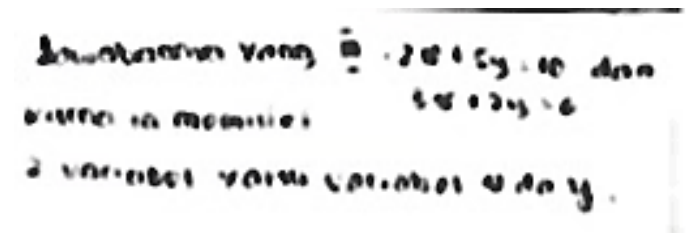

Gambar 11. Jawaban Subjek ML Untuk Indikator Ketiga Hari I

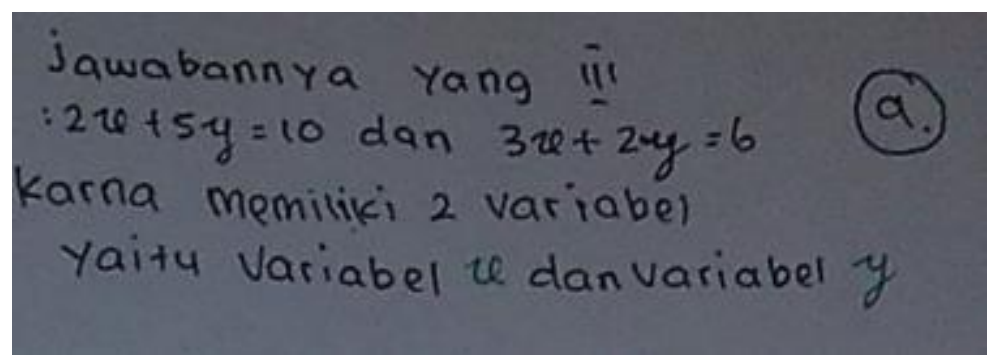

Gambar 12. Jawaban Subjek ML Untuk Indikator Ketiga Hari II

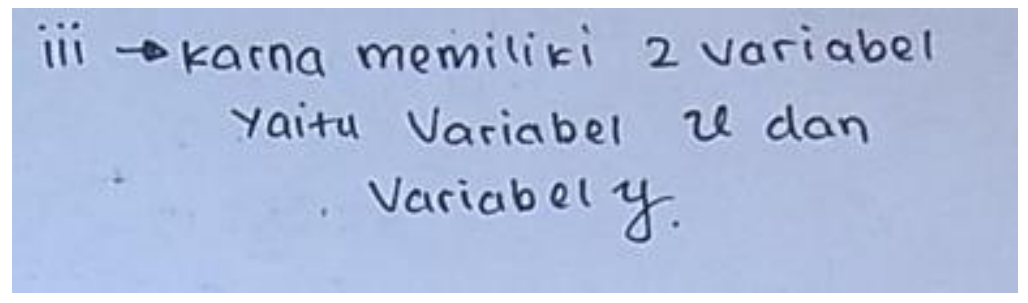

Gambar 13. Jawaban Subjek ML Untuk Indikator Ketiga Hari III

Tidak ada kesamaan yang banyak dari ledua subjek kinestetik ML dan SAH, namun secara keseluruhan dapat disimpulkan bahwa subjek dengan gaya belajar kinestetik cenderung menginterpretasikan jawaban secara singkat, akan tetapi masih jelas, mereka lebih suka langsung menjelaskan perhitungannya untuk menemukan jawaban yang diinginkannya seperti yang ditampilkan pada gambar 14.

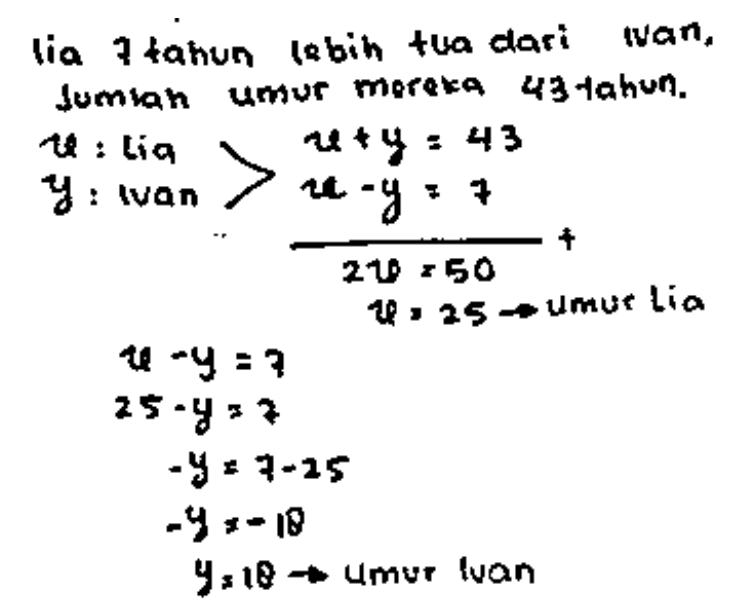

Gambar 14. Jawaban Subjek SAH Untuk Indikator Ketujuh 


\section{KESIMPULAN}

Berdasarkan hasil dan diskusi, diperoleh simpulan bahwa peserta didik yang mempunyai gaya belajar visual menuangkan interpretasinya dalam pemahaman konsep materi sistem persamaan linear dua variabel dengan sistematis dan rinci, serta mampu menyajikan grafik dengan jelas, dan memenuhi seluruh indikator pencapaian pemahaman konsep, sehingga peserta didik yang mempunyai gaya belajar visual dapat dikatakan mempunyai pemahaman konsep yang lebih baik dari peserta didik yang memiliki gaya belajar auditorial dan kinestetik. Pada peserta didik yang memiliki gaya belajar auditorial dan kinestetik, keduanya juga dapat dikatakan cukup memahami konsep SPLDV, namun masih kurang baik dalam membedakan contoh dan bukan contoh dari konsep SPLDV. Peserta didik dengan gaya belajar kinestetik juga masih belum cukup mampu untuk menerapkan algoritma menggunakan prosedur serta konsep dalam menyelesaikan masalah SPLDV.

Dari kesimpulan yang telah ditarik, perbedaan gaya belajar memberi kontribusi daan keterkaitan terhadap kemampuan pemahaman konsep yang dimiliki peserta didik, maka peneliti perlu memberikan saran kepada pendidik agar hendaknya lebih memperhatikan gaya belajar peserta didik dengan cara menyajikan model pembelajaran yang kreatif dan inovatif sehingga pemahaman konsep setiap gaya belajar yang dimiliki peserta didik dapat diakomodasi sesuai kebutuhan. Mengembangkan dan melatih kemampuan pemahaman konsep matematika juga dibutuhkan bagi peserta didik sesuai dengan gaya belajar yang ada dalam dirinya. Selanjutnya, peneliti berharap penelitan ini dapat menjadi gambaran mengenai pemahaman konsep matematika berdasarkan gaya belajar peserta didik, juga dapat menjadi rujukan untuk penelitian selanjutnya.

\section{DAFTAR PUSTAKA}

Astari, T. (2018). Analisis Motivasi Dan Gaya Belajar Terhadap Hasil Belajar. Jurnal Ilmu Pendidikan Guru dan Sosial, 1(1), 1-9.

Diana, P., Marethi, I., \& Pamungkas, A. S. (2020). Kemampuan Pemahaman Konsep Matematis Siswa: Ditinjau dari Kategori Kecemasan Matematik. SJME (Supremum Journal of Mathematics Education), 4(1), 24. https://doi.org/10.35706/sjme.v4i1.2033

Hasanah, M., \& Mutiani, M. (2019). Pemahaman Wajib Belajar 12 Tahun di Sekolah Bawang Banjarmasin. $\begin{array}{lllll}\text { Bubungan Tinggi: Jurnal Pengabdian } & \text { Masyarakat, } & 1(1), & 15 .\end{array}$ https://doi.org/10.20527/btjpm.v1i1.1783

Jaenudin, Nindiasari, H., \& Pamungkas, A. S. (2017). Analisis Kemampuan Berpikir Reflektif Matematis Siswa Ditinjau Dari Gaya Belajar. Prima: Jurnal Pendidikan Matematika, 1(1), 69. https://doi.org/10.31000/prima.v1i1.256

Karunia, E. P., \& Mulyono. (2016). Analisis kemampuan pemahaman konsep siswa kelas VII berdasarkan gaya belajar dalam model knisley. Prosiding Seminar Nasional Matematika, 339. https://doi.org/10.1016/j.ijmecsci.2014.08.026

Kepa, S. (2019). Analisis Pemahaman Konsep Dan Kemampuan Pemecahan Masalah Perbandingan 
Trigonometri Ditinjau dari Gaya Belajar Siswa SMA Negeri 1 Banda Neira. Journal on Pedagogical Mathematics, 1(2), 72-85.

Muhardi. (2005). Kontribusi Pendidikan Dalam Meningkatkan Kualitas Bangsa Indonesia. Journal Unisba, XX(4), 478-492. https://ejournal.unisba.ac.id/index.php/mimbar/article/view/153

Nurhidayah, D. A. (2015). Pengaruh Motivasi Berprestasi dan Gaya Belajar Terhadap Prestasi Belajar Siswa Pada Mata Pelajaran Matematika SMP. Jurnal Dimensi Pendidikan Dan Pembelajaran, 3(2), 13-24. https://doi.org/http://dx.doi.org/10.24269/dpp.v3i2.83

Sugiyono. (2013). Metode Penelitian Kuantitatif, Kualitatif, Dan R\&D. Alfabeta.

Susilaningsih, E., Fatimah, S., \& Nuswowati, M. (2019). Analysis Of Students' Conceptual Understanding Assisted By Multirepresentation Teaching Materials in the Enrichment Program. KnE Social Sciences, 2019, 85-98. https://doi.org/10.18502/kss.v3i18.4701

Wahyuni, Y. (2017). Identifikasi Gaya Belajar (Visual, Auditorial, Kinestetik) Mahasiswa Pendidikan Matematika Universitas Bung Hatta. Jurnal Penelitian dan Pembelajaran Matematika, 10(2), 128132. https://doi.org/10.30870/jppm.v10i2.2037

Wijayanti, A., Safitri, P. T., \& Raditya, A. (2018). Analisis Pemahaman Konsep Limit Ditinjau Dari Gaya Belajar Interpersonal. Prima: Jurnal Pendidikan Matematika, 2(2), 157. https://doi.org/10.31000/prima.v2i2.714

Yulia. (2019). Analisis Pemahaman Siswa Terhadap Konsep Segi Empat (Studi Kasus Pada Siswa Kelas VII SMP Negri 1 Sindue). Ilmiah Pendidikan Matematika, 2(1), 24.

Yulianty, N. (2019). Kemampuan Pemahaman Konsep Matematika Siswa Dengan Pendekatan Pembelajaran Matematika Realistik. Jurnal Pendidikan Matematika Raflesia, 4(1), 60-65. https://doi.org/10.33449/jpmr.v4i1.7530 